Marine Pollution Bulletin

November 2009, Volume 58, Issue 11, Pages 1727-1733

http://dx.doi.org/10.1016/j.marpolbul.2009.06.012

http://orbi.ulg.ac.be/handle/2268/26339

(c) 2009 Elsevier Ltd All rights reserved.
Archimer

Archive Institutionnelle de l'Ifremer http://www.ifremer.fr/docelec/

\title{
Assessment of the ecological status of Mediterranean French coastal waters as required by the Water Framework Directive using the Posidonia oceanica Rapid Easy Index: PREI
}

\author{
Sylvie Gobert ${ }^{a,{ }^{*}}$, Stéphane Sartoretto ${ }^{b}$, Valérie Rico-Raimondino ${ }^{c}$, Bruno Andral $^{b}$, Aurelia \\ Chery $^{d}$, Pierre Lejeune ${ }^{d}$ and Pierre Boissery ${ }^{e}$
}

\footnotetext{
a MARE Centre, Laboratoire d'Océanologie, Université de Liège, Sart-Tilman, B6, 4000 Liège, Belgium

${ }^{b}$ IFREMER, Zone Portuaire de Brégaillon, 83500 La Seyne-sur-mer, France

${ }^{c}$ Région Provence-Alpes-Côte d'Azur Service Mer 27 Place Jules Guesde, 13481 Marseille Cedex 20, France

d STARESO, Pointe Revellata BP33, 20260 Calvi, France

e Agence de l'Eau Rhône-Méditerranée-Corse, 62 La Canebière, 13001 Marseille, France
}

*: Corresponding author: S. Gobert, Tel.: +32 436633 29; fax: +32 436651 47, email address : Sylvie.Gobert@ulg.ac.be

\begin{abstract}
:
This paper describes the PREI (Posidonia oceanica Rapid Easy Index), a method used to assess the ecological status of seawater along Mediterranean French coasts. The PREI was drawn up according to the requirements of the Water Framework Directive (WFD 2000/60/EC) and was tested on 24 and 18 stations in PACA (Provence-Alpes-Côtes d'Azur) and Corsica, respectively. The PREI is based on five metrics: shoot density, shoot leaf surface area, E/L ratio (epiphytic biomass/leaf biomass), depth of lower limit, and type of this lower limit. The 42 studied stations were classified in the first four levels of status: high, good, moderate and poor. The PREI values ranged between 0.280 and 0.847 ; this classification is in accordance with our field knowledge and with our knowledge of the literature. The PREI was validated regarding human pressure levels $\left(r^{2}=0.74\right)$. (http://eurex.europa.eu/LexUriServ/LexUriServ.do?uri=OJ:L:2000:327:0001:0072:EN:PDF).
\end{abstract}

Keywords: Seagrass; Posidonia oceanica; Mediterranean Sea; Coastal water; Ecological Quality Ratio; Water Frame Directive 


\section{Introduction}

The seagrass Posidonia oceanica (L.) Delile is an endemic species of the Mediterranean Sea. It forms monospecific meadows widely distributed between the surface and $44 \mathrm{~m}$ depth in the clearest waters (Malta, France (Var, Corsica)) (Augier and Boudouresque, 1979; Boudouresque et al., 1980; Boudouresque et al., 1990; Borg and Schembri, 1995). These meadows cover large areas in coastal regions totalling a global surface area of $37,000 \mathrm{~km}^{2}$ (1 to $2 \%$ of the bottom of the Mediterranean Sea (Pasqualini et al. 1998; Boudouresque et al., 2006). Posidonia meadows constitute an engineering ecosystem playing a major ecological, geological and economic role in coastal zones (Boudouresque and Meinesz, 1982; PergentMartini et al., 1994; Francour, 1997; Boudouresque, 2004). The meadows are sensitive to human disturbance such as coastal development, pollution, increasing water turbidity and trawling (Boudouresque et al., 2000, Boudouresque et al., 2006). They are now listed as a priority natural habitat in Annex I of the EC Directive 92/43/EEC on the Conservation of Natural Habitats and of Wild Fauna and Flora (EEC, 1992) but the loss of covering has been described in a large number of regions around the Mediterranean Sea.

Programmes for monitoring Posidonia beds initiated in Europe (Spain, France, Italy) have allowed the definition of the quality of coastal waters (Boudouresque et al., 2007), and $P$. oceanica is regularly used as a bioindicator because of its sensitivity to disturbance (Pergent-Martini, 1998; Gosselin et al., 2006; Leoni et al., 2006; Montefalcone, 2009).

Due to the increase in anthropogenic pressure on ecosystems and the associated water quality decline, the European Union has engaged a new strategy to conserve and recover the ecological quality of the marine environment. In order to attain this objective, the Water Framework Directive (WFD) has established the basis of policies for the monitoring, protection and enhancement of the status of aquatic systems in the Member States. The main goal of the WFD is to achieve (or maintain at least) a "good water status" for all the European waters by 2015. To this end, this directive defines the concept of ecological status as the quality of the structure and functioning of ecosystems associated with homogenous water bodies. The evaluation of the status of each water body is based on the use of some organisms or groups of organisms sensitive to anthropogenic pressures: biological quality elements (BQEs).

Phytoplankton, macroalgae, angiosperms and benthic fauna are the BQEs to be considered (Devlin et al., 2007). According to the WFD, biological variables indicative of the status of these BQEs should be used for evaluation and monitoring purposes. On the basis of previous work on the bioindicating of water global quality by Posidonia oceanica, this species was chosen for the Mediterranean area as the angiosperm BQE (Med-GIG, 2007). As permitted by the WFD, each member state, involved in this BQE, can define its own method to evaluate the state of the Posidonia oceanica meadow.

For example, the PosWare (system for coastal water classification by using $P$. oceanica as quality element according to WFD) (Buia et al., 2005), the POMI (multivariate index based on the seagrass Posidonia oceanica) (Romero et al., 2007 and corrigendum), Valencian CS (Fernandez Torquemada et al., 2006; 2008) and BiPO (Biotic index using P.oceanica) (Lopez y Royo, 2008), have been developed to evaluate the status of coastal waters based on the $P$. oceanica BQE (Table 1; see also Table 9).

Table 1 
This paper describes the PREI (Posidonia oceanica Rapid Easy Index) method used along PACA (Provence-Alpes-Côte d'Azur) and Corsican coasts to implement the assessment of French coastal waters using $P$. oceanica under the WFD. It presents the first results and validations (agreement of metrics used with the impact of anthropic pressure).

\section{Methodology}

\subsection{Selection and measurement of the metrics}

A lot of descriptors (or metrics) have already been used to assess the health status of P.oceanica meadows around the Mediterranean Sea (Pergent-Martini et al., 2005). These metrics provide information:

(i) at different levels (population and community levels, individual, tissue...);

(ii) on different types of disturbance;

(iii) with different times of response (week, year, century...) (Table 2).

In this study, we calculated the PREI with five metrics measured in P.oceanica meadows to define the ecological status of French Coastal Waters according to the WFD recommendations: (1) shoot density, (2) shoot surface, (3) E/L (ratio between epiphytic biomass and leave biomass) measured on shoots sampled at the same depth; (4) depth of the lower limit and (5) type of this limit (regressive, progressive or stable).

Firstly, these metrics were selected because they provide pertinent information on the vitality of the meadow (at the individual and population level) for a wide spectrum of disturbance (water transparency, nutrient concentrations and eutrophization, sedimentary dynamics, grazing pressure...) regularly described in the Mediterranean Sea (Pergent-Martini et al., 2005). As such, they constitute unequivocal indicators of Posidonia oceanica (Dale and Beyeler, 2001). They are also easy to obtain with a good cost-efficiency ratio and low technological investment.

Table 2

\subsection{Calculation of EQR and classification of water body}

According to the WFD, the classification of ecological status is based on the deviation of the status of the BQE from its potential status under pristine conditions (reference conditions: RC). This ecological status is expressed using a scale going from 1 (RC) to 0 (worst conditions where the BQE is badly affected or missing). The ratio between the status of a given $B Q E$ noted in a station and its status in the reference conditions is called the Ecological Quality Ratio (EQR).

To calculate this EQR, a definition of $R C$ has to be made. RC describe the characteristics in undisturbed conditions. These conditions should be established using i) the best spatial analysis (data from undisturbed sites), ii) palaeoecological and historical data, iii) modelling using existing or historical data and iiii) expert judgment. Due to the impossibility of Posidonia oceanica surviving in extremely degraded environments (Boudouresque et al., 2006; Romero et al., 2007), its presence defines the quality of water bodies above a "bad" status (Romero et al., 
2007). The "bad" condition has been defined as a condition corresponding to a recorded recent die-off of the meadow ( $<5$ years) due to identified anthropogenic impacts (Med-GIG, 2007).

On this basis, considering that no pristine conditions could be found in the studied area, we postulated RC as a "theoric optimal site", corresponding to the best values of each metric noted in the field. We defined EQR' as an index integrating the averaging of the chosen individual metrics:

$>\mathrm{EQR}^{\prime}=(\mathrm{N}$ density $+\mathrm{N}$ leaf surface area $+\mathrm{N}(\mathrm{E} / \mathrm{L})+\mathrm{N}$ lower limit $) / 3.5$

with:

- $\mathrm{N}$ density = value measured-0/reference value- 0 ;

- $\mathrm{N}$ leaf surface area = value measured-0/reference value-0;

0 being considered as the worst value for the density and for the leaf surface area.

$-\mathrm{N}(\mathrm{E} / \mathrm{L})=[1-(\mathrm{E} / \mathrm{L})] \times 0.5$;

- $\mathrm{N}$ lower limit $=$ (value measured-17)/ (reference value -17$), 17 \mathrm{~m}$ being considered as the worst lower limit for Posidonia meadows

$N^{\prime}=$ depth noted on the field $+\lambda$, where $\lambda=0$ (stable limit), $\lambda=3$ (progressive limit) or $\lambda=-3$ (regressive limit).

As considered by Romero et al. (2007) for the definition of the POMI index, we arbitrarily assigned an EQR value of 0.100 for the "bad" status boundary; the other EQR boundaries were obtained by dividing the remaining scale (from 0.100 to 1 ) into four categories of equal amplitude (Table 3). Therefore, where P. oceanica existed, the EQR was computed as follows:

$>\mathrm{EQR}=\left(\mathrm{EQR}^{\prime}+0.11\right) /(1+0.10)$

Table 3

\subsection{Application of the method to the French Coast}

The PREI index was applied in two French hydrographic districts (zones defined by article 2 of the WFD) representing a coastal of $1840 \mathrm{~km}$ (Gobert et al., 2008): Corsica and PACA.

In total, 42 stations were sampled, distributed as follows: 24 in PACA and 18 in Corsica (Fig.1). These studied sites comprised different human impact conditions (low to highly impacted). All stations were characterized by the presence of P.oceanica meadows that therefore excluded a bad classification $(E Q R<0.100)$.

Around Corsica, meadows colonize sandy and/or rocky bottom in very clear waters with very low island discharges (Gosselin et al., 2006). The PACA area is characterized by sandy or rocky or mixed meadows colonizing clear waters with low natural continental discharge (Blanc and Jeudy de Grissac, 1978). But two stations located at the extreme west of this region (Ponteau and Couronne) are exposed to the impact of the Rhône estuary and the "Mistral" wind (NW wind), inducing general high turbidity and sedimentary deposit (Blanc and Jeudy de Grissac, 1978; Sartoretto, 1996).

Fig. 1

The sampling was performed at a $15 \mathrm{~m}$ depth in April (2007) to prevent the masking effects of depth and seasonal variability (Middelboe et al., 2003; Alcoverro et al., 
1995). At each station, shoot density, depth and type of lower limit were noted in situ by a scuba diver. Twenty shoots of $\mathrm{P}$. oceanica were collected for the laboratory measurements (biometry and E/L). Methods used to obtain each metric are detailed in Table 4.

\section{Table 4}

The mean value of each metric was used to calculate the EQR' and EQR of each station as described above.

\subsection{Definition of RC}

Topography, salinity, turbidity, hydrodynamism, genetics, ... clearly influence shoot biometry and meadow structure (i.e. Procaccini and Mazzella, 1998). The meadows of the two studied areas: (Corsica and PACA) also exhibit differences within the French basin in relation to the topography. Around Corsica, the seawater is characterized by oligotrophic conditions (low nutrient concentration, low turbidity...) In PACA, natural continental discharges are more important (Goffart et al., 2000; Gobert et al., 2002...).

In our study, the most important difference appears for the lower depth limit. We only considered the lower depth of meadows with stable limits to avoid anthropogenic effects (five both in Corsica and in PACA); mean values were $37 \mathrm{~m} \pm 1$ for Corsica and $25 \mathrm{~m} \pm 3$ for PACA. For this parameter, the spatial variation is evident and is related to light penetration and to turbidity (Elkalay et al., 2003).

Knowing this spatial variability, the RC (Table 5) to calculate the EQR were determined separately for the 2 hydrological districts (Corsica and PACA).

The reference value was defined for each metric in each district. The RC were calculated using data obtained in April 2007; furthermore we used our field data together with literature data in order to establish the lower depth limit, (e.g. Boudouresque et al., 2000, Mayot, 2007...).

For density and leaf surface area, the reference values were calculated as the mean of the three higher values of the considered metric after the maximum one was discarded. For $E / L$, we postulated that 0 was the reference value, which corresponded to a non epiphyted shoot.

Table 5

\section{Results}

The 42 studied stations were classified in the first four levels of status: high, good, moderate and poor. The PREI values ranged between 0.280 and 0.847 (Table 6). Two meadows (8\%) received the status of poor in PACA (Corbière and Villefranches); $16 \%$ and $22 \%$ were qualified as moderate, $62 \%$ and $67 \%$ as good, $13 \%$ and $11 \%$ as high both in the PACA area and along the coast of Corsica. The mean PREI EQR in PACA was slightly lower than along the coast of Corsica (0.609 and 0.635 respectively). 
Along the French Mediterranean coasts, a large proportion of economic activities are based on tourism. The coastal zone is dedicated to tourists (hotels, marinas, camping, ...) but the area has also seen an increase in population and in urbanization (Benoit and Comeau, 2005). The levels of pollution are difficult to establish regarding the very high variability of sources (type of pollution, local or diffuse source...).

In order to verify the robustness of our PREI, we calculated an anthropization index. The anthropization index was defined as the sum of 7 impact factors affecting the seawater quality and /or biotope quality: fish farming, industrial development, agriculture, tourism, fishing, commercial ports and urbanization. Each impact factor was classified from 0 (no impact) to 5 (dramatic effect on the meadow) according to criteria listed in Table 7.

The proximity of the study stations to Marine Protected Areas (Francour et al., 2001) and literature data was also taken into account. (Boudouresque et al., 2000).

\section{Table 7}

The quality of seawater expressed by our anthropization index was negatively correlated with the PREI (Fig. 2).

The lowest anthropization indices $(=1)$ were attained by 3 Corsican and 3 PACA stations (Bravone, Erbalunga, Aregno and Levant, Blénat, Cap Roux respectively); Ponteau and Corbière (PACA District) were the highest anthropized stations with an index of 20.

Most of the Corsican sites had a high or good ecological status with a mean anthropization index of 3.8.

Corsican coasts are subject to a lower anthropogenic pressure (no high level industrial activities and no highly urbanized areas) than continental zones.

Four stations were classified as moderate: Ajaccio-sud, Porto Pollo, Sant'Amanza $\mathrm{fdb}$, Saint Florent. The Ajaccio-sud site is in a semi-closed area where sewers, marinas and aquaculture are active. Porto Pollo is an enclosed area principally developed for tourism; anchoring systems which do not damage the seafloor are installed but it seems that urban discharges are uncontrolled. The site Sant'Amanza $\mathrm{fdb}$ is an enclosed zone, which is subject to the effects of fish farming in a well developed tourist zone. Saint Florent is a semi-enclosed area where marina, fishing and agricultural activities are listed.

The case of Ajaccio-nord (high anthropization index: 10 - good ecological status) can be explained by the position of the sampling point: an open zone in an urbanized area where the anthropogenic pressures do not reach and do not affect the meadow.

The majority of stations in the PACA District (82\%) were classified as having a high or good ecological status, with a mean anthropization index of 5.0. Four sites were considered as moderate: Ponteau, Couronne, La Vesse and Plateau des Chèvres. Ponteau is located in a Gulf (Gulf of Fos) highly impacted by human activities (anthropization index: 20) and directly exposed to the Rhône Delta water. According to this description, the EQR value is close to the boundary values between moderate and poor ecological status (EQR= 0.325$)$. The case of Couronne (low anthropization index: 6 - moderate ecological status) can be explained by the exposure to Gulf of Fos water through the existence of the Nerthe countercurrent (Blanc and Jeudy de Grissac, 1978). EQR values for La Vesse and Plateau des Chèvres were consistent 
with a high level of anthropization index (11) (urbanization, commercial harbour, sewage outfall,...). Finally, two stations were considered to be in a poor ecological state: Corbière and Villefranche are particularly impacted by human activities linked to the proximity of big urban centres and portuary zones.

Fig. 2

In order to test the robustness of the PREI index, we acquired in April 2008, new data on 3 stations classified as "good" with Posidonia oceanica BQE: Prado, Brusc and Carqueiranne (PACA District). Results obtained show a very small variation in EQR values between 2007 and 2008, less than 1.5\% (Table 8).

Table 8

The main source of variation is the ratio $\mathrm{E} / \mathrm{L}$ but its impact is limited by low values $(<0.2)$.

\section{Discussion}

The results of the ecological classification by the PREI are in accordance with our field knowledge and with our knowledge of the literature. The PREI, based on $P$. oceanica metrics that integrate responses at individual and community levels, is an efficient method to define the quality of coastal water.

Our indices reflect the main anthropogenic factors that were found to occur in littoral zones and the quality of seawater expressed by our anthropization index was negatively correlated with the PREI. The robustness of the PREI was checked on three stations prospected over two successive years.

Some indices, based on $P$. oceanica, have been proposed to assess Mediterranean coastal waters in accordance with the WFD (Tables 2 and 9) (Fernandez Torquemada et al., 2008; Romero et al., 2007; Lopez y Rojo, 2008). An intercallibration exercise of Posidonia indices between countries in the WFD is in progress.

Table 9 presents a summary of some characteristics these indices.

\section{Table 9}

Our index is a destructive technique, requiring scuba divers, using shoot density, the most adopted standardized descriptor (Montefalcone, 2009). All stations were sampled during a short period (10 days), which avoided seasonality effects. The PREI is both cost effective and easily applied. It requires scuba divers working on random punctual stations (15 $\mathrm{m}$ depth) and on positioned stations (depth limit).

Montefalcone (2009) recently recommended an integrated approach based on descriptors of water quality together with three ecological indices of ecosystem health (Conservation Index (Moreno et al., 2001), Substitution Index and Phase Shift Index) in order to discriminate the main components affecting the status of coastal ecosystems.

This approach is more complex and requires experienced divers (\% of covering, knowledge of biology to determine substituting species) but was able to be tested in 
the Bay of Calvi near STARESO (with Cl corresponding to good conservation status; $\mathrm{SI}$ and PSI corresponding to high conservation status on a $100 \mathrm{~m}$ transect at $10 \mathrm{~m}$ depth; Gobert, personal unpublished data, June 2009).

\section{Conclusions}

The Posidonia Rapid Easy Index (PREI) was used to assess the ecological status of Mediterranean French coastal waters in accordance with WFD requirements (EC, 2000) and with decisions taken within the Mediterranean Intercallibration Group (Med-GIG, working group (including authors of this paper) (Med-GIG, 2007). It is a reliable approach for estimating the state of $P$.oceanica meadows and the ecological status of seawater.

For the PREI, we selected metrics that were easy to obtain (with a minimum of laboratory analysis) and easy to measure (without requiring scientific expertise).

Cost effectiveness was also an important issue. The PREI was compared to the level of human pressure on the environment (anthropization indices); its robustness was tested by the acquisition of new data in 2008 on the same stations as in 2007. It can be easily used by coastal managers.

\section{Acknowledgements}

The study was funded by the Agence de l'eau, Ifremer, FRS-FNRS (2.4502.08) and by the French community of Belgium (ARC Race 05/10/333). We acknowledge the anonymous referees whose comments improved the quality of the manuscript. This publication has the MARE publication number MARE171.

\section{References}

Alcoverro, T., Duarte, C.M., Romero, J. 1995. Annual growth dynamics of Posidonia oceanica: contribution of large-scale versus local factors to seasonality. Marine Ecology Progress Series 120, 203-210.

Augier, H., Boudouresque, C.F. 1979. Premières observations sur l'herbier de Posidonie et le détritique côtier de l'île du Levant (Méditerranée, France), à l'aide du sous-marin « Griffon » de la Marine Nationale. Travaux Scientifique du Parc National de Port-Cros 5, 141-153.

Benoit, G., Comeau, A. 2005. Méditerranée. Les perspectives du Plan Bleu sur l'environnement et le développement. L'Aube (France), 428pp.

Blanc, J.J, Jeudy de Grissac, A. 1978. Recherches de géologie sédimentaire sur les herbiers à Posidonies du littoral de la Provence. Contrat CNEXO 76/4043, 77/4074. Centre National d'Exploitation des Océans publication, Fr, 1-185, i-vii+42 pl. h.t.

Borg, J.A., Schrembi, P.J. 1995. The state of Posidonia oceanica (L.) Delile meadows in the Maltese Islands (Central Mediterranean). Rapport P.V. Réunion de la Commission International pour l'Exploration Scientifique de Méditerranée 34, 1123.

Boudouresque, C.F. 2004. Marine biodiversity in the Mediterranean: status of species, populations and communities. Scientific Reports of the Port-Cros National Park 20, 97-146. 
Boudoureque, C.F., Charbonel, E., Meinesz, A., Pergent, G., Pergent-Martini, C., Cadiou, G., Bertrandy, M.C., Foret, P., Rico-Raimondino, V. 2000. A monitoring network based on the seagrass Posidonia oceanica in the Northwerstern Mediterranean Sea. Biologia Marina Mediterranea 7 (2), 328-331.

Boudouresque, C.F., Giraud, G., Perret-Boudouresque, M. 1980. Bibliography on vegetation and ecosystems of Posidonia oceanica, Part II. Excerpta Botanica 20 (2B), 125-135.

Boudouresque, C.F., Meinesz, A. 1982. Découverte de l'herbier de Posidonies. Cahier du Parc National de Port-Cros 4, 1-79.

Boudouresque, C.F., Bianconi, C.H., Meinesz, A. 1990. Live Posidonia oceanica in a coralligenous algal ban kat Sulana, Corsica. Rapport P.V. Réunion de la Commission International pour l'Exploration Scientifique de Méditerranée 32(1), p.11.

Boudouresque, C.F, Bernard, G., Bonhomme, P., Charbonnel, E., Diviacco, G., Meinesz, A., Pergent, G., Pergent-Martini, C., Ruitton, S., Tunesi, L. 2006. Préservation et conservation des herbiers à Posidonia oceanica. Ramoge pub., 1202.

Boudouresque, C.F., Bernard, G., Bonhomme, P., Charbonnel, E., Le Diréach, L., Ruitton, S. 2007. Monitoring methods for Posidonia oceanica meadows in Provence and French Riviera. Scientific Reports of the Port-Cros National Park 22: 17-38.

Buia, M.C., Silvestre, F., Iacono, G., Tiberti, L. 2005. Identificazione delle biocenosi di maggior preggio ambientale al fine della classificazione della qualita delle acque costiere. In:. Metodologie per il rilevamento e la classificazione dello stato di qualita ecologico e chimico delle acque, con particolare riferimento all'aplicazione del decreto legislativo 152/99. APAT, Rome, 269-303.

CIS-WFD, 2003. Common Implementation Strategy for the Water Framework Directive (2000/60/EC). Guidance Document no. 5: Coastal and Transitional Waters: Typology, Reference Conditions and Classification Systems. Working Group 2.4. Office for the official publications of the European communities, Luxembourg, 1-107. ISBN 92-894-5125-4.

Dale, V.H., Beyeler, S.C. 2001. Challenges in the development and use of ecological indicators. Ecological Indicators 1, 3-10.

Dauby, P., Poulicek, M. 1995. Methods for removing epiphytes from seagrasses: SEM observations on treated leaves. Aquatic Botany 52, 217-228.

Devlin, M. Besyt, M., Haynes, D. 2007. Implementation of the Water Framework Directive in European Marine Waters. Marine Pollution Bulletin 55 (1-6), 1-2.

EEC, 1992. Council Directive 92/43/EEC on the conservation of natural habitats and of wild fauna and flora. Official Journal of the European Communities. No L 2006 July 1992. El Asmi-Djellouli, Z., Djellouli, A.S., Pergent-Martini, C., Pergent, P., Abdeljaoued, S., El Abed, A., 2006. Interactions entre l'herbier à Posidonia oceanica et l'hydrodynamisme au sein de la baie de Monastir. UNEP-MAP-RAC/SPA. Proceedings of the second Mediterranean symposium on marine vegetation (Athens, 12-13 December 2003) RAC-SPA edit. Tunis 255pp;

Elkalay, K., Frangoulis, C., Skliris, N., Goffart, A., Gobert, S., Lepoint, G., Hecq, J.H. 2003 model of the seasonal dynamics of biomass and production of the seagrass Posidonia oceanica in the Bay of Calvi (Northwestern Mediterranean). Ecological Modelling. 167: 1-18.

Fernandez Torquemada, Y., Diaz Valdes, M., Luna, B., Sanchez Lizaso, J.L., Ramos, A.A. 2006. "Evaluación preliminar de la calidad de las praderas de Posidonia oceanica de la Comunidad Valenciana dentro de la Directiva Marco del Agua". XIV Simposio Ibérico de Estudios de Biología Marina. Libro de resúmenes, 123-124.

Fernandez Torquemada, Y., Diaz Valdes, M., Luna, B., Colilla, F., Luna, B., Sanchez Lizaso, J.L., Ramos, A.A. 2008. Descriptors from Posidonia oceanica (L.) Delile meadows in coastal waters of Valencia, Spain, in the context of the EU Water Framework Directive. ICES Journal of Marine Science. 65: 1492-1497. 
Francour, P. 1997. Fish assemblages of Posidonia oceanica beds at Port-Cros (France, NW Mediterranean): Assessment of composition and long-term fluctuations by visual census. Marine Ecology PSZNI 18(2): 157-173.

Francour, P., Harmelin, J.G., Pollard, D., Sartoretto, S. 2001. A review of marine protected areas in the northwestern Mediterranean region: siting, usage, zonation and management. Aquatic Conservation Marine and Freshwater Ecosystems 11: 155-158.

Giraud, G. 1979. Sur une méthode de mesure et de comptage des structures foliaires de Posidonia oceanica (L.) Delile. Bulletin du Museum d'Histoire Naturel de Marseille 39, 33-39.

Gobert, S., Andral, B., Boissery, P., Chery, A., Lejeune, P., Pelaprat, C., RicoRaimondino, V., Sartoretto, S. 2008. Soutien méthodologique à la mise en œuvre de la Directive Cadre Eau item: Herbier de Posidonie: Validation du protocole de calcul de l'EQR. Ifremer-Université de Liège-STARESO-Agence de l'eau. 55pp.

Gobert, S., Laumont, N., Bouquegneau, J.M. 2002. Posidonia oceanica meadow: a low nutrient high chlorophyll system (LNHC)? BMC Ecology 2:9. http://hdl.handle.net/2268/11513.

Goffart, A., Hecq, J.H., Legendre, L. 2002. Changes in the development of winter-spring phytoplankton bloom in the Bay of Calvi (Northwestern Mediterranean) over the last two decades: a response to changing climate? Marine Ecology Progress Series 236:45-60.

Gosselin, M., Bouquegneau, J.M., Lefebvre, F., Lepoint, G., Pergent, G., PergentMartini, C., Gobert, S. 2006. Trace metal concentrations in Posidonia oceanica of North Corsica (northwestern Mediterranean Sea): use as a biological monitor? BMC Ecology 6:1. http://hdl.handle.net/2268/1210.

Leoni, V. Pasqualini, V. Pergent-Martini, C. Vela, A., Pergent, G. 2006. Morphological responses of Posidonia oceanica to experimental nutrient enrichment of the canopy water. Journal of Experimental Marine Biology and Ecology 339, 1-14.

Lopez y Royo, C. 2008. Utilisation de Posidonia oceanica (L.) Delile comme outil de gestion de la qualité écologique du milieu marin. PhD Thesis Université de Corse, 1242.

Mayot, N. 2007. Changements à long terme des limites inférieures de Posidonia oceanica en Provence et Côte d'Azur. PhD Thesis Université de la Méditerranée (Aix-Marseille II), 142pp.

Med-GIG, 2007. WFD Intercalibration technical report for coastal and transitional waters in the Mediterranean ecoregion. In: WFD Intercalibration technical report Part 3: Coastal and transitional waters. Available from: http://circa.europa.eu/Public/irc/jrc/jrc_eewai/library?l=/intercalibration_2\&vm=detaile $\mathrm{d} \& \mathrm{sb}=$ Title

Meinesz, A., Laurent, R. 1978. Cartographie et état de la limite inférieure de l'herbier de Posidonia oceanica dans les Alpes-Maritimes. Campagne «Poseidon » 1976. Botanica Marina 21, 513-526.

Middelboe, A.L., Sand-Jansen, K., Krause-Jensen, D. 2003. Spatial and interannual variations with depth in eelgrass populations. Journal of Experimental Marine Biology 291, 1-15.

Montefalcone, M. 2009. Ecosystem health assessment using the Mediterranean seagrass Posidonia oceanica: A review. Ecological Indicators 9: 595-604.

Moreno, D., Aguilera, P.A., Castro, H. 2001. Assessment of the conservation status of seagrass (Posidonia oceanica) meadows: implications for monitoring strategy and the decision-making process. Biological Conservation 102: 325-322.

Pasqualini, V. Pergent-Martini, C. Clabaut, P. Pergent, G. 1998. Mapping of Posidonia oceanica using aerial photographs and side-scan sonar: application of the islands of Corsica (France). Estuarine Coastal Shelf Science 47, 359-367. 
Pergent-Martini, C. Rico-Raimondino, V. Pergent, G. 1994. Primary production of Posidonia oceanica in the Mediterranean basin. Marine Biology 120, 9-15.

Pergent-Martini, C. 1998. Posidonia oceanica: a biological indicator of past and present mercury contamination in the Mediterranean Sea. Marine Environmental Research 45 (2), 101-111.

Pergent-Martini, C., Leoni, V., Pasqualini, V., Ardizzone, G.D., Balestri, E., Bedini, R., Belluscio, A., Belsher, T., Borg, J., Boudouresque, C.F., Boumaza, S., Bouquegneau, J.M., Buia, M.C., Calvo, S., Cebrian, J., Charbonnel, E., Cinelli, F., Cossu, A., Di Maida, G., Dural, B., Francour, P., Gobert, S., Lepoint, G., Meinesz, A., Molenaar, H., Mansour, H.M., Panayotidis, P., Peirano, A., Pergent, G., Piazzi, L., Pirrota, M., Relini, G., Romero, J., Sanchez-Lizaso, J.L., Semroud, R., Shembri, P., Shili, A., Tomasello, A., Velimirov, B., 2005. Descriptors of Posidonia oceanica meadows: use and application. Ecological Indicators 5, 213-230.

Procaccini and Mazzella, 1998 INSERT REFERENCE??

Romero, J., Martinez-Crego, B., Alcoverro, T., Perez, M. 2007. A multivariate index based on the seagrass Podidonia oceanica (POMI) to assess ecological status of coastal waters under the Water Framework Directive (WFD). Marine Pollution Bulletin 55, 196-204.

Romero, J., Martinez-Crego, B., Alcoverro, T., Perez, M. 2007. Corrigendum of: "A multivariate index based on the seagrass Podidonia oceanica (POMI) to assess ecological status of coastal waters under the Water Framework Directive (WFD) in Marine Pollution Bulletin 55, 196-204". Marine Pollution Bulletin 54, 631

Sartoretto, S. 1996. Vitesse de croissance et de bioérosion des concrétionnements "coralligène" de Méditerranée nord-occidentale. Rapport avec les variations Holocènes du niveau marin. PhD Th., Université d'Aix-Marseille II, Fr., 1-194.

Silvestre, F., lacono, G., Tiberti, L., Buia C.M. 2006. Posidonia oceanica warehousing. Biological Marine Mediterranean 13, 277-281.

Soullard, M., Bourge, I., Fogel, J., Lardinois, D., Mathieu, T., Veeschens, C., Bay, D., Dauby, P., Bouquegneau J.M. 1994. Evolution de la densité de l'herbier de Posidonie de la baie de Calvi (Corse). Vie Milieu 44, 199-201. 
Tables

\begin{tabular}{|c|c|c|c|}
\hline & Metrics & Methods & Reference \\
\hline Posware & $\begin{array}{l}\text {-shoot density, } \\
\text {-width of the } \\
\text { intermediate leaf, - } \\
\text { leaf production, } \\
\text {-rhizome production, } \\
\text {-rhizome elongation }\end{array}$ & $\begin{array}{c}\text { combined in a } \\
\text { datawarehouse (Autoclass } \\
\text { C, miner 3D, and fuzzy } \\
\text { clustering analyses) }\end{array}$ & Buia et al., 2005 \\
\hline POMI & $\begin{array}{l}\text {-shoot density, } \\
\text {-meadow cover, } \\
\text {-percentage } \\
\text { plagiotropic rhizomes, } \\
\text {-shoot leaf surface, } \\
\text {-percentage foliar } \\
\text { necrosis, } \\
\mathrm{P}, \mathrm{N} \text { and sucrose } \\
\text { content in rhizomes, } \\
-\delta^{15} \mathrm{~N} \text { and } \delta^{34} \mathrm{~S} \\
\text { isotopic ratio in } \\
\text { rhizomes, } \\
-\mathrm{N} \quad \text { content in } \\
\text { epiphytes, } \\
-\mathrm{Cu}, \mathrm{Pb}, \text { and Zn } \\
\text { content in rhizomes }\end{array}$ & $\begin{array}{l}\text { combined using Principal } \\
\text { Component Analysis } \\
\text { (PCA) }\end{array}$ & Romero et al., 2007 \\
\hline Valencian CS & $\begin{array}{l}\text {-shoot density, } \\
\text {-meadow cover, } \\
\text {-dead matte cover, } \\
\text {-percentage of } \\
\text { plagiotropic rhizomes, } \\
\text {-rhizome } \\
\text { baring/burial, } \\
\text {-shoot leaf surface } \\
\text { area, } \\
\text {-percentage of foliar } \\
\text { necrosis, } \\
\text {-herbivore pressure, } \\
\text {-leaf epiphyte } \\
\text { biomass. }\end{array}$ & $\begin{array}{c}\text { combined using Principal } \\
\text { Component Analysis } \\
\text { (PCA) }\end{array}$ & $\begin{array}{l}\text { Fernandez Torquemada } \\
\text { et al., 2006;2008 }\end{array}$ \\
\hline BIPo & $\begin{array}{l}\text {-lower depth limit, } \\
\text {-lower limit type, } \\
\text {-shoot density, } \\
\text {-shoot leaf surface }\end{array}$ & $\begin{array}{l}\text { combined by averaging } \\
\text { metric scores }\end{array}$ & Lopez y Royo, 2008 \\
\hline
\end{tabular}

Table 1: Four methods based on Posidonia oceanica in the WFD to assess the ecological status of Mediterranean coastal waters

\begin{tabular}{c|l|l|ll}
\hline TYPE & VARIABLE & IMPACT OR STRESS & RESPONSE & \\
\hline & $\begin{array}{l}\text { Shoot density } \\
\left(\text { shoot } / \mathbf{m}^{2}\right)\end{array}$ & $\begin{array}{l}\text { Reduction of light availability. } \\
\text { Burial. Direct elimination due to } \\
\text { trawl fishing, boat anchoring, } \\
\text { coastal construction, etc. }\end{array}$ & $\begin{array}{l}\text { Shoot density decrease } \\
\text { (shoot mortality) }\end{array}$ & \\
\cline { 3 - 4 } & Cover (\%) & $\begin{array}{l}\text { Reduction of light availability. } \\
\text { Burial. Direct elimination due to } \\
\text { trawl fishing, boat anchoring, } \\
\text { coastal construction, etc. }\end{array}$ & $\begin{array}{l}\text { Vegetal } \\
\text { decrease }\end{array}$ & coverage \\
\cline { 3 - 5 } & & & & \\
\hline
\end{tabular}




\begin{tabular}{|c|c|c|c|}
\hline TYPE & VARIABLE & IMPACT OR STRESS & RESPONSE \\
\hline & "Matte" structure & $\begin{array}{l}\text { Disturbance on sedimentary } \\
\text { flux. Burial. Boat anchoring, } \\
\text { coastal construction, etc. }\end{array}$ & $\begin{array}{l}\text { Fragilization of the "matte" } \\
\text { structure }\end{array}$ \\
\hline & $\begin{array}{l}\text { Epiphyte } \\
\left(\mathrm{mg} / \mathrm{cm}^{2}\right)\end{array}$ biomass & Reduction of light availability & $\begin{array}{l}\text { Epiphyte } \\
\text { decrease }\end{array}$ \\
\hline & \multirow{3}{*}{$\begin{array}{l}N \text { content in epiphyte } \\
\text { species associated to } \\
\text { meadow }\end{array}$} & Eutrophication & $\begin{array}{lr}\text { Epiphyte r biomass } \\
\text { increase, except if } \\
\text { compensated } \\
\text { herbivores. }\end{array}$ \\
\hline & & Eutrophication & Increase in tissues \\
\hline & & $\begin{array}{l}\text { Reduction of light availability. } \\
\text { Burial. Direct elimination due to } \\
\text { trawl fishing, boat anchoring, } \\
\text { coastal construction, etc. }\end{array}$ & Decrease of biodiversity \\
\hline \multirow{5}{*}{2} & $\begin{array}{l}\text { Foliar area } \\
\left(\mathrm{cm}^{2} / \text { shoot }\right)\end{array}$ & $\begin{array}{|lr|}\text { Reduction of light availability } \\
\text { Eutrophication } & \text { (turbidity } \\
\text { increase due to phytoplankton } \\
\text { development) }\end{array}$ & $\begin{array}{l}\text { Leaf surface increase to } \\
\text { optimize photosynthetic } \\
\text { productivity }\end{array}$ \\
\hline & $\begin{array}{l}\text { Foliar necrosis }(\% \\
\text { leaves with necrosis } \\
\text { lshoot) }\end{array}$ & Eutrophication & $\begin{array}{l}\text { Possible consumption by } \\
\text { herbivores due to nutrient } \\
\text { increase }\end{array}$ \\
\hline & & $\begin{array}{l}\text { Reduction of light availability. } \\
\text { Prolonged anoxia (burial). Other } \\
\text { stress factors (e.g. toxins, } \\
\text { pathogens, hypersalinity) }\end{array}$ & $\begin{array}{l}\text { Increase in necrosis in } \\
\text { tissues }\end{array}$ \\
\hline & Lepidochronology & $\begin{array}{l}\text { Reduction of light availability, } \\
\text { sediment resuspension... }\end{array}$ & $\begin{array}{l}\text { Changes in foliar } \\
\text { productivity and the growth } \\
\text { rate of the rhizomes }\end{array}$ \\
\hline & $\begin{array}{l}\text { Plagiotropic } \\
\text { rhizomes (\%) }\end{array}$ & $\begin{array}{l}\text { Reduction of light availability, } \\
\text { sediment resuspension... }\end{array}$ & $\begin{array}{l}\text { Decrease of percentage of } \\
\text { plagiotropic rhizomes }\end{array}$ \\
\hline \multirow{7}{*}{3} & Sucrose content & $\begin{array}{l}\text { Reduction of light availability } \\
\text { due to eutrophication, sediment } \\
\text { resuspension...Burial }\end{array}$ & $\begin{array}{l}\text { Decrease of carbon } \\
\text { reserves in rhizomes }\end{array}$ \\
\hline & $\begin{array}{l}\text { Nitrogen and } \\
\text { phosphorus content }\end{array}$ & Eutrophication & $\begin{array}{l}\text { Increase of nutrient } \\
\text { content in plant }\end{array}$ \\
\hline & & Reduction of light availability & $\begin{array}{l}\text { Increase of nutrient } \\
\text { content (nitrogen) in leaves } \\
\text { due to low growth under } \\
\text { low light conditions } \\
\end{array}$ \\
\hline & & Anoxia in sediment & $\begin{array}{l}\text { Decrease of nutrients } \\
\text { accumulated in rhizomes } \\
\text { due to negative effects on } \\
\text { the availability and uptake } \\
\text { of nutrients by roots }\end{array}$ \\
\hline & $\delta{ }^{15} \mathrm{~N}$ and $\delta^{34} \mathrm{~S}$ & Eutrophication & Increase of $\delta^{15} \mathrm{~N}$ \\
\hline & & Anoxia in sediment & Increase of $\delta^{34} \mathrm{~S}$ \\
\hline & $\begin{array}{l}\text { Metal traces: } \mathrm{Cu}, \mathrm{Zn} \\
\text { and } \mathrm{Pb}\end{array}$ & Metal contamination & $\begin{array}{l}\text { Increase of metals in } \\
\text { tissues. Effects on } \\
\text { photosynthetic activity (Cu, } \\
\mathrm{Pb}, \mathrm{Zn})\end{array}$ \\
\hline
\end{tabular}

Table 2: List of main descriptors of P.oceanica used in monitoring and their responses to different impacts, 1: community descriptors, 2: individual descriptors, 3: physiological descriptors (Pergent-Martini et al., 2005; Boudouresque et al., 2006; Romero et al., 2007). 


\begin{tabular}{lll}
\hline EQR & ECOLOGICAL STATUS & CoLOR CODE \\
\hline $1-0.775$ & High & Blue \\
$0.774-0.550$ & Good & Green \\
$0.549-0.325$ & Moderate & Yellow \\
$0.324-0.100$ & Poor & Orange \\
$<0.100-0$ & Bad & Red \\
\hline
\end{tabular}

Table 3: Boundaries and colour codes for the different levels of ecological status

\begin{tabular}{|c|c|}
\hline PREI METRICS AND UNITS & METHODOLOGY AND REFERENCES \\
\hline Shoot density (shoot.m²) & $\begin{array}{l}\text { Quadrat } 20 \times 20 \mathrm{~cm} \text { (Soullard et al., 1994) } \\
20 \text { measurements at } 15 \mathrm{~m} \text { depth }\end{array}$ \\
\hline Lower depth limit (m) & Noted in situ by scuba diver \\
\hline $\begin{array}{l}\text { Type of this limit } \\
\text { (regressive, progressive, } \\
\text { stable) }\end{array}$ & $\begin{array}{l}\text { Noted in situ by scuba diver according to the classification of } \\
\text { Meinesz and Laurent, } 1978\end{array}$ \\
\hline$E / L$ & $\begin{array}{l}\text { On } 20 \text { shoots sampled at } 15 \mathrm{~m} \text { depth: measurement of total dry } \\
\text { weight of epiphyte and leaf (adult+intermediate) (Dauby and } \\
\text { Poulicek, 1995) }\end{array}$ \\
\hline $\begin{array}{l}\text { Leaf surface area } \\
\left(\mathrm{cm}^{2} \text {. } \text { shoot }^{-1}\right)\end{array}$ & $\begin{array}{l}\text { On } 20 \text { shoots sampled at } 15 \text { m depth: measurement of total leaf } \\
\text { surface area according to the methodology of Giraud (1979) }\end{array}$ \\
\hline
\end{tabular}

Table 4: List of metrics used in the PREl, unit and methodology used to obtain the results for each metric

\begin{tabular}{l|l|l}
\hline & CORSICA & PACA \\
\hline Shoot density (shoot/m²) & 483 & 675 \\
Leaf surface area (cm²/shoot) & 546 & 465 \\
E/L & 0 & 0 \\
Lower depth limit (m) & 41 & 34 \\
\hline
\end{tabular}

Table 5: Reference conditions for each metric in the two studied French Hydrographic Districts (PACA and Corsica)

\begin{tabular}{ll|ll}
\hline \multicolumn{2}{c|}{ CORSICA } & \multicolumn{2}{c}{ PACA } \\
\hline STATION & PREI & STATION & PREI \\
\hline Cargèse & $\mathbf{0 . 6 6 8}$ & Ponteau & 0.360 \\
Tiucca & $\mathbf{0 . 6 3 0}$ & Couronne & $\mathbf{0 . 5 2 5}$ \\
Ajaccio nord & $\mathbf{0 . 5 6 4}$ & Carry & 0.680 \\
Ajaccio sud & $\mathbf{0 . 4 9 5}$ & Ensuès & 0.686 \\
Porto Pollo & $\mathbf{0 . 3 8 6}$ & La Vesse & 0.465 \\
Figari-Bruzzi & $\mathbf{0 . 6 1 9}$ & Corbière & $\mathbf{0 . 3 0 5}$ \\
Piantarella & $\mathbf{0 . 5 9 7}$ & Nord Pomègues & $\mathbf{0 . 6 2 8}$ \\
Sant'Amanza fdb & $\mathbf{0 . 5 4 2}$ & Prado & 0.636 \\
Sant'Amanza eb & $\mathbf{0 . 6 7 1}$ & P. Chèvres & 0.477
\end{tabular}




\begin{tabular}{ll|ll} 
Large Diana & $\mathbf{0 . 6 8 9}$ & Riou & $\mathbf{0 . 6 7 7}$ \\
Bravone & $\mathbf{0 . 7 7 9}$ & Calanque & $\mathbf{0 . 5 8 4}$ \\
Taglio Isolaccio & $\mathbf{0 . 6 9 0}$ & Cassis & $\mathbf{0 . 5 6 3}$ \\
Large Biguglia & $\mathbf{0 . 7 2 1}$ & Figuerolle & $\mathbf{0 . 6 6 0}$ \\
Erbalunga & $\mathbf{0 . 7 4 1}$ & Bandol & 0.682 \\
Maccinagio & $\mathbf{0 . 6 5 0}$ & Brusc & 0.634 \\
St Florent & $\mathbf{0 . 4 7 8}$ & Carqueiranne & $\mathbf{0 . 7 0 8}$ \\
Aregno & $\mathbf{0 . 7 8 9}$ & Garonne & 0.583 \\
Calvi & $\mathbf{0 . 7 2 4}$ & Levant & 0.802 \\
& & Giens & 0.819 \\
& & Bénat & 0.764 \\
& & St Raphael & 0.690 \\
& & Cap Roux & 0.847 \\
& & Antibes & 0.560 \\
& & Villefranche & 0.280 \\
\hline
\end{tabular}

Table 6: PREI values calculated in Corsica and PACA

\begin{tabular}{|c|c|c|}
\hline IMPACT FACTORS & CRITERIA & REFERENCE \\
\hline Fish Farming & Number, production. & \multirow{7}{*}{$\begin{array}{l}\text { Benoit and Comeau, 2005, } \\
\text { Boudouresque et al., 2000, } \\
\text { Pasqualini et al., 1999,. } \\
\text { http://observatoire.oec.fr; } \\
\text { http://www.corse.eaufrance.fr } \\
\text { http://www.rhone- } \\
\text { mediterranee.eaufrance.fr }\end{array}$} \\
\hline Industrial development & Type, zoning, & \\
\hline Agriculture & Exploited surface, type of exploitation & \\
\hline Tourism & $\begin{array}{l}\text { Number of camping,, marina, beach and } \\
\text { second home; tourism fluxes (airport, } \\
\text { ferries...), }\end{array}$ & \\
\hline Fishing & $\begin{array}{l}\text { Fishing, fleetfishing port, employment, type } \\
\text { of activity (artisanal, deep-sea...) }\end{array}$ & \\
\hline Commercial port & Harbour traffic, type of activities & \\
\hline Urbanization & Sewer, Population density & \\
\hline
\end{tabular}

Table 7: List of impact factors and criteria used to calculate the anthropization index

\begin{tabular}{llllll}
\hline & DENSITY & LEAF SURFACE & E/L & EQR 2007 & EQR 2008 \\
\hline PRADO & $\begin{array}{l}-9 \% \\
(p<0.05)\end{array}$ & $\begin{array}{l}+15 \% \\
(p<0.0005)\end{array}$ & $\begin{array}{l}+41 \% \\
(p<0.0005)\end{array}$ & 0.631 & 0.632 \\
BRUSC & $-2.3 \%$ & $\begin{array}{l}-1.4 \% \\
(N S)\end{array}$ & $\begin{array}{l}+120 \% \\
(p<0.0005)\end{array}$ & 0.628 & 0.623 \\
CARQUEIRANNE & $\begin{array}{l}\text { (NS) } \\
-5.5 \%\end{array}$ & $\begin{array}{l}+3.4 \% \\
(N S)\end{array}$ & $\begin{array}{l}+29 \% \\
(p<0.05\end{array}$ & 0.702 & 0.693 \\
& & & & & \\
\hline
\end{tabular}

Table 8: Variation in metrics and EQR between 2007 and 2008 for three stations classified as "good" by the PREI index. NS: non significant variation. 


\begin{tabular}{|c|c|c|c|c|c|}
\hline & PosWare & POMI & ECS Valencia & BIPo & PREI \\
\hline Number of metrics & 6 & 14 & 9 & 4 & 5 \\
\hline \multirow[t]{2}{*}{ Sampling conditions } & $x$ & & September-October & August-September & April \\
\hline & & & $14-17 m$ & 15m and lower limit & 15m and lower limit \\
\hline $\begin{array}{l}\text { In situ measurement } \\
\text { Sampling effort }\end{array}$ & $x$ & $\begin{array}{l}\text { yes } \\
+++\end{array}$ & $\begin{array}{l}\text { yes } \\
++++\end{array}$ & $\begin{array}{l}\text { yes } \\
++\end{array}$ & $\begin{array}{l}\text { yes } \\
+\end{array}$ \\
\hline $\begin{array}{l}\text { Laboratory measurement } \\
\text { Laboratory work }\end{array}$ & $x$ & $\begin{array}{l}\text { yes } \\
+++++\end{array}$ & $\begin{array}{l}\text { yes } \\
+++\end{array}$ & no & $\begin{array}{l}\text { yes } \\
+\end{array}$ \\
\hline Laboratory material & $x$ & $\begin{array}{l}\text { Sophisticated } \\
\text { (ICPS; IRMS...) }\end{array}$ & $\begin{array}{l}\text { Simple } \\
\text { (quadrat, measure ribbon...) }\end{array}$ & $\begin{array}{l}\text { Simple } \\
\text { (quadrat, measure ribbon...) }\end{array}$ & $\begin{array}{l}\text { Simple } \\
\text { (quadrat, measure ribbon,...) }\end{array}$ \\
\hline Destructive method & $x$ & yes & yes & no & yes \\
\hline Cost & $x$ & expensive & cheap & cheap & cheap \\
\hline \multicolumn{6}{|l|}{ Test of robustness } \\
\hline -against anthropic pressures & $x$ & yes & yes & yes & yes \\
\hline -temporal variation & $x$ & no & yes & no & yes \\
\hline Geographical test & Italy & $\begin{array}{l}\text { Catalan coast } \\
\text { (Spain) }\end{array}$ & $\begin{array}{l}\text { Valencia coast } \\
\text { (Spain) }\end{array}$ & $\begin{array}{l}\text { Corsican coast } \\
\text { (France) }\end{array}$ & $\begin{array}{l}\text { Corsican coast and PACA } \\
\text { (France) }\end{array}$ \\
\hline
\end{tabular}

$\mathrm{x}$ : PosWare is based on data collected in a data warehouse, data coming from monitoring projects on large spatial and temporal scale 
Table 9: Comparison of the application of POMI, BIPO and PREI

\section{Figures}




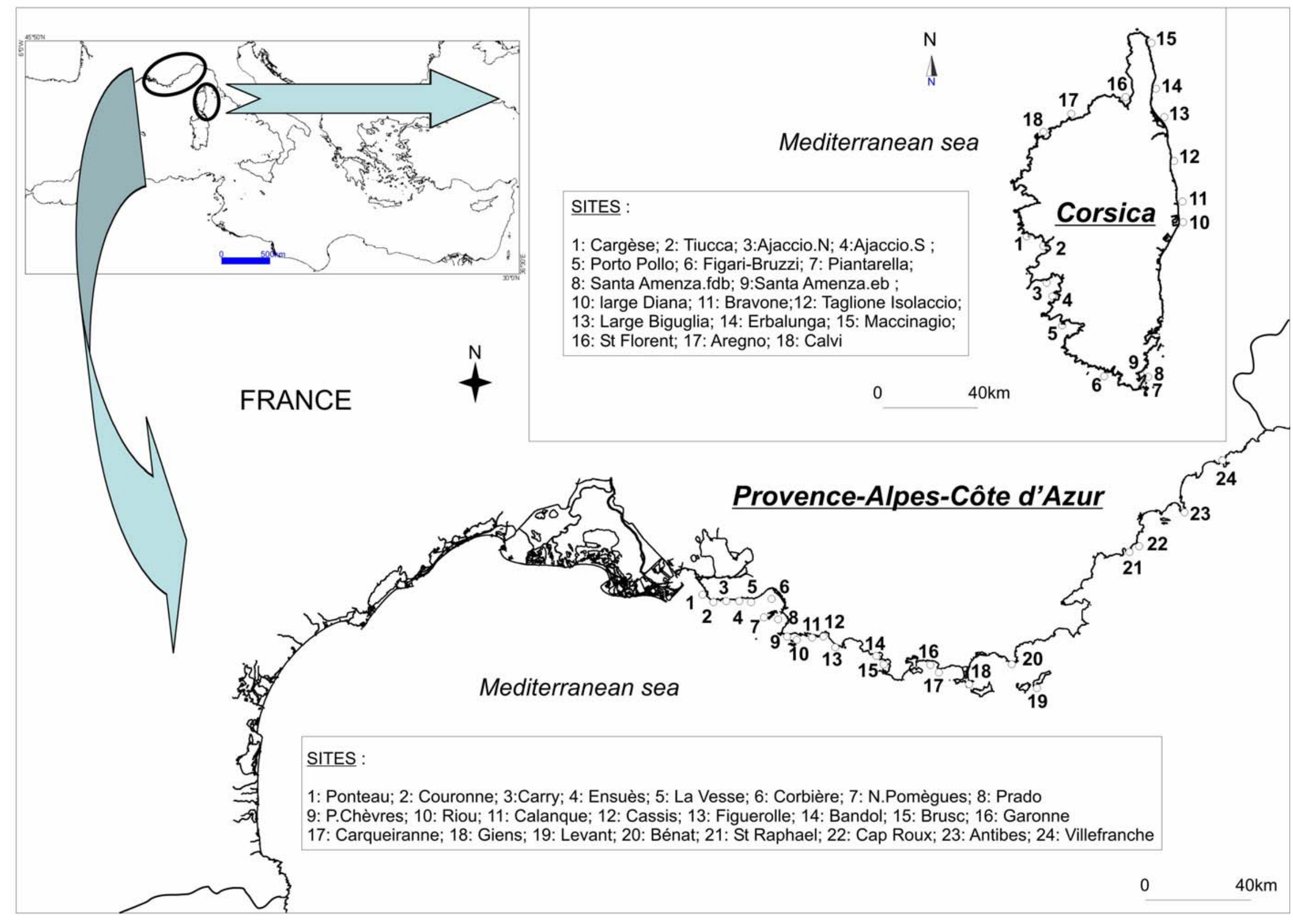


Figure 1: Location of the 42 sampling marine sites in the two studied French Hydrographic Districts (PACA and Corsica)

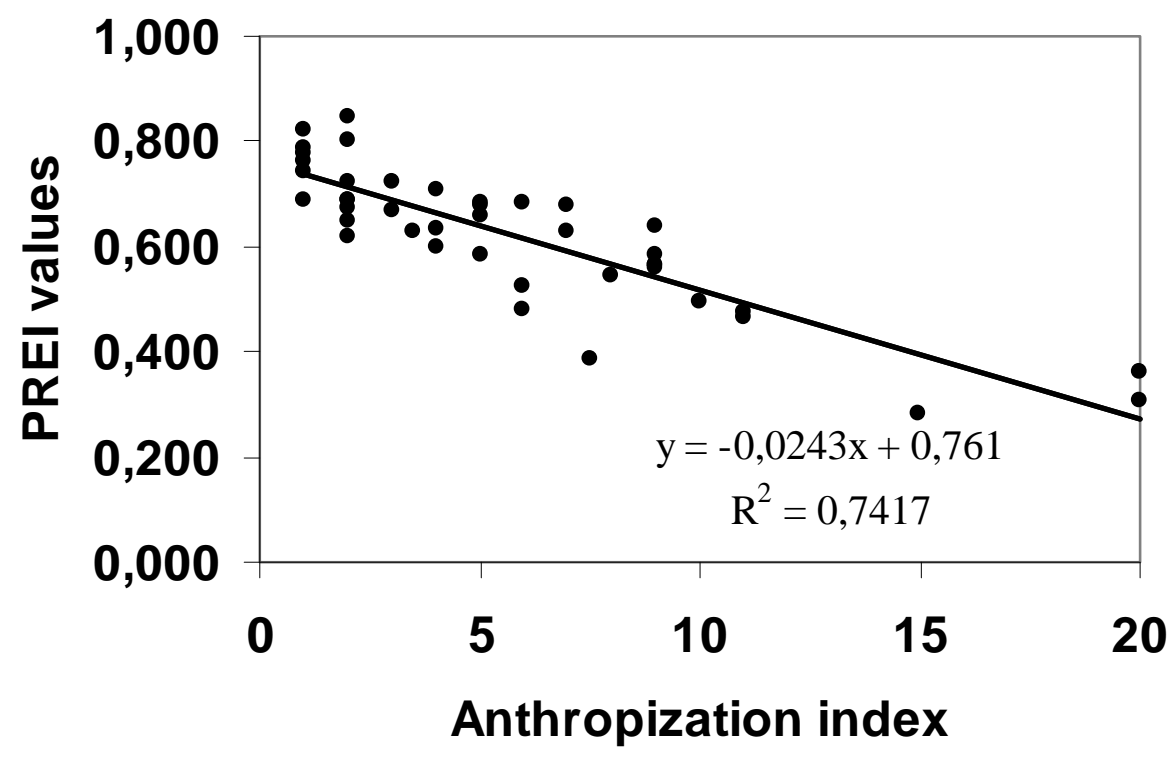

Figure 2: Regression between the anthropization index of water bodies and the classification obtained by the PREI index 